\title{
Efficacy of the quick sequential organ failure assessment for predicting clinical outcomes among community-acquired pneumonia patients presenting in the emergency department
}

\author{
Xiangqun Zhang, Bo Liu, Yugeng Liu, Lijuan Ma and Hong Zeng*
}

\begin{abstract}
Background: The study aimed to investigate the predictive value of the quick sequential organ failure assessment (qSOFA) for clinical outcomes in emergency patients with community-acquired pneumonia (CAP).

Methods: A total of 742 CAP cases from the emergency department (ED) were enrolled in this study. The scoring systems including the GSOFA, SOFA and CURB-65 (confusion, urea, respiratory rate, blood pressure and age) were used to predict the prognostic outcomes of CAP in ICU-admission, acute respiratory distress syndrome (ARDS) and 28-day mortality. According to the area under the curve (AUC) of the receiver operating characteristic (ROC) curves, the accuracies of prediction of the scoring systems were analyzed among CAP patients.

Results: The AUC values of the GSOFA, SOFA and CURB-65 scores for ICU-admission among CAP patients were 0.712 (95\%Cl: $0.678-0.745, P<0.001), 0.744$ (95\%Cl: $0.711-0.775, P<0.001)$ and 0.705 (95\%Cl: $0.671-0.738, P<0.001$ ), respectively. For ARDS, the AUC values of the qSOFA, SOFA and CURB-65 scores were 0.730 (95\%Cl: $0.697-0.762$, $P<0.001$ ), 0.724 (95\%Cl: $0.690-0.756, P<0.001)$ and 0.749 (95\%Cl: $0.716-0.780, P<0.001$ ), respectively. After 28 days of follow-up, the AUC values of the qSOFA, SOFA and CURB-65 scores for 28-day mortality were 0.602 (95\%Cl: $0.566-0.638, P<0.001$ ), 0.587 (95\%Cl: $0.551-0.623, P<0.001$ ) and 0.614 (95\%Cl: $0.577-0.649, P<0.001$ ) in turn. There were no statistical differences between qSOFA and SOFA scores for predicting ICU-admission $(Z=1.482, P=0.138)$, $\operatorname{ARDS}(Z=0.321, P=0.748)$ and 28-day mortality $(Z=0.573, P=0.567)$. Moreover, we found no differences to predict the ICU-admission $(Z=0.370, P=0.712)$, ARDS $(Z=0.900, P=0.368)$ and 28-day mortality $(Z=0.768, P=0.442)$ using qSOFA or CURB-65 scores.
\end{abstract}

Conclusion: qSOFA was not inferior to SOFA or CURB-65 scores in predicting the ICU-admission, ARDS and 28-day mortality of patients presenting in the ED with CAP.

Keywords: Quick sequential organ failure assessment, Community-acquired pneumonia, ICU-admission, Acute respiratory distress syndrome, 28-day mortality

\footnotetext{
* Correspondence: hongzeng2708@163.com

Department of Emergency, Beijing Chao-Yang Hospital, Capital Medical

University, No.5 Jingyuan Road, Shijingshan District, Beijing 100048, P.R. China
}

\section{$\triangle B M C$}

C C The Author(s). 2020 Open Access This article is licensed under a Creative Commons Attribution 4.0 International License, which permits use, sharing, adaptation, distribution and reproduction in any medium or format, as long as you give appropriate credit to the original author(s) and the source, provide a link to the Creative Commons licence, and indicate if changes were made. The images or other third party material in this article are included in the article's Creative Commons licence, unless indicated otherwise in a credit line to the material. If material is not included in the article's Creative Commons licence and your intended use is not permitted by statutory regulation or exceeds the permitted use, you will need to obtain permission directly from the copyright holder. To view a copy of this licence, visit http://creativecommons.org/licenses/by/4.0/ The Creative Commons Public Domain Dedication waiver (http://creativecommons.org/publicdomain/zero/1.0/) applies to the data made available in this article, unless otherwise stated in a credit line to the data. 


\section{Background}

Community-acquired pneumonia (CAP) is a common infectious disease with high morbidity, mortality and medical costs [1], and is caused by various microorganisms such as bacteria, viruses, chlamydia and mycoplasma outside the hospital. Previous studies reported that approximately $20 \%$ of CAP adult patients needed to be hospitalized for treatment, and the mortality is as high as 30-50\% [2]. The incidence of severe CAP needing admission to intensive care unit (ICU) is gradually rising due to septic shock and the requirement of invasive mechanical ventilation (IMV) [3]. The evidence has shown that severe CAP can induce the occurrence of acute respiratory distress syndrome (ARDS) which is a life-threatening disease with a present mortality of nearly $40 \%$ [4]. Therefore, it is significant for the clinicians to early predict the outcomes of CAP, accurately and objectively assess the severity of the disease to optimize therapeutic strategies.

To date, several assessment tools for CAP patients have been applied in the emergency department (ED), such as the quick sequential organ failure assessment (qSOFA) [5, 6], sequential organ failure assessment (SOFA) [7, 8], and confusion, urea, respiratory rate, blood pressure and age (CURB-65) scores [9-12]. Of these, the qSOFA score is recently developed to predict the death of infected patients which was proposed by the Sepsis-3 group in 2016 [13]. The advantage of the qSOFA score is on the basis of three clinical criteria (respiratory rate, mental status and blood pressure), without the requirement for laboratory tests. To the best of our knowledge, however, the predictive efficacy of these scoring systems on the pneumonia severity has rarely reported among patients with CAP.

Although some reports suggested that the qSOFA score is effective for predicting the mortality in CAP $[14,15]$, it is uncertain whether the qSOFA score can be used to evaluate other prognostic outcomes, such as ICUadmission and ARDS. Accordingly, we assessed the predictive value of qSOFA score for clinical outcomes in emergency patients with CAP, and the efficacy of the qSOFA score was explored in comparison with other pneumonia severity scoring systems (SOFA and CURB-65 scores) in ICU-admission, ARDS and 28-day mortality.

\section{Methods}

\section{Patients}

This investigation was conducted at Beijing Chao-Yang Hospital from Nov. 2011 to Sep. 2018. A total of 742 CAP cases were enrolled, containing 462 males and 280 females. The characteristics of patients were recorded including age, gender, past medical history and vital signs. The whole blood leukocyte counts, blood gas indexes, blood biochemistry and X-ray results were detected within $24 \mathrm{~h}$. According to the findings of vital signs and laboratory examination, the qSOFA, SOFA and CURB-65 scores were calculated.

\section{Inclusion and exclusion criteria}

Patients who met the following criteria were included: (1) age > 18 years; (2) corresponding to diagnosis criteria of CAP.

Exclusion criteria were: (1) advanced diseases including malignant tumors (advanced or metastasized tumors), end-stage liver or renal disease; (2) hospitalization within 14 days before symptom appearance; (3) cystic fibrosis, active pulmonary tuberculosis, severe immunosuppression, coagulopathy or systemic anticoagulant treatment; (4) pretreatment outside the hospital; and (5) the patients or relatives did not agree to participate in the study.

\section{Diagnosis criteria}

Diagnosis criteria for patients with CAP conformed to new infiltration on the chest with at least one of the following symptoms: (1) cough; (2) sputum; (3) dyspnea; (4) core body temperature $>38.0^{\circ} \mathrm{C}$; (5) auscultation with abnormal breath sounds or rales [16].

Berlin diagnostic criteria for ARDS were utilized on the basis of oxygenation index as follows: (1) mild: 200 $\mathrm{mmHg}<\mathrm{PaO}_{2} / \mathrm{FIO}_{2} \leq 300 \mathrm{mmHg}$; (2) moderate: 100 $\mathrm{mmHg}<\mathrm{PaO}_{2} / \mathrm{FIO}_{2} \leq 200 \mathrm{mmHg} ;$ (3) severe: $\mathrm{PaO}_{2} /$ $\mathrm{FIO}_{2} \leq 100 \mathrm{mmHg}$. Four ancillary indicators for severe ARDS were considered including radiographic severity, respiratory system compliance $\left(\leq 40 \mathrm{~mL} / \mathrm{cm} \mathrm{H}_{2} \mathrm{O}\right)$, positive end-expiratory pressure ( $\mathrm{PEEP}, \geq 10 \mathrm{~cm} \mathrm{H}_{2} \mathrm{O}$ ) and corrected exhaled minute volume $(\geq 10 \mathrm{~L} / \mathrm{min})$ [17].

In the present study, we conducted a 28-day follow-up research to assess the outcomes. The occurrence of ARDS and 28-day mortality were served as the endpoint events, and ICU admission was also included as an outcome of patients within $72 \mathrm{~h}$ of ED visit. Patients who survived after the last follow-up were considered as survivors.

\section{Laboratory examination}

Hospitalization within $12 \mathrm{~h}, 5-10 \mathrm{~mL}$ blood was collected in the tubes containing heparin or ethylenediaminetetraacetate (EDTA), then stored at $-80^{\circ} \mathrm{C}$. White blood cell (WBC) were measured via an automated hematology analyzer (Sysmex XS-500i, Sysmex Corporation Kobe, Japan). Plasma lactate (Lac) levels were detected by a blood gas analyzer (GEM Premier 3000, Instrumentation Laboratory, Lexington, MA, USA), and the normal range was $0.7-2.5 \mathrm{mmol} / \mathrm{L}$. The concentrations of serum procalcitonin (PCT) were measured using a BioMerieux Mini VIDAS immunoassay analyzer (Block Scientific, Bohemia, NY, USA), and the limit of detection (LOD) was $0.05 \mathrm{ng} /$ $\mathrm{mL}$. Serum C-reactive protein (CRP) concentrations were analyzed utilizing turbidimetric immunoassay (BNII, Siemens Healthcare Diagnostic, Germany). 


\section{Statistical analysis}

Statistical analysis was performed using SPSS 16.0 (SPSS Inc., Chicago, IL, USA). Normally distributed data were expressed by mean \pm standard deviation (SD), while nonnormally distributed data were denoted via median $\left(\mathrm{P}_{25}\right.$, $\mathrm{P}_{75}$ ). Mann-Whitney $\mathrm{U}$ test was used for the comparison between the two groups, and Kruskal-Wallis one-way analysis was utilized for the multi-group comparisons. Lac, PCT, WBC, CRP, qSOFA, SOFA and CURB-65 scores were analyzed in ICU-admission, ARDS and 28-day mortality, and we mentioned the receiver operating characteristic (ROC) curves and determined the area under curves (AUC). We also calculated the sensitivity, specificity, positive predictive value (PPV) and negative predictive value (NPV). Compared with AUCs, the formula of $\mathrm{Z}$ test is: $\mathrm{Z}=\left(A_{1}-A_{2}\right)$ / $\left(S E_{1}^{2}+S E_{2}^{2}-\mathrm{r} S E_{1} S E_{2}\right)^{1 / 2} \quad\left(\mathrm{Z}_{0.05}=1.96, \mathrm{Z}_{0.01}=2.58\right)$. The independent predictors of ICU-admission, ARDS and 28-day mortality were confirmed by Binary Logistic regression analysis. All statistical analyses were the two-tailed tests, and $P<$ 0.05 was considered statistically significant.

\section{Results}

The baseline data of the emergency patients with CAP A total of 1028 patients from ED were enrolled in this study. Among these subjects, 152 patients with

Table 1 The baseline data of the patients with CAP

\begin{tabular}{|c|c|c|c|c|c|c|c|c|c|}
\hline Characteristics & $\begin{array}{l}\mathrm{ICU} \\
(n=174)\end{array}$ & $\begin{array}{l}\text { Non-ICU } \\
(n=568)\end{array}$ & $P$ & $\begin{array}{l}\text { ARDS } \\
(n=164)\end{array}$ & $\begin{array}{l}\text { Non-ARDS }(n= \\
578)\end{array}$ & $P$ & $\begin{array}{l}\text { Survivor } \\
(n=443)\end{array}$ & $\begin{array}{l}\text { Non-Survivors }(n= \\
299)\end{array}$ & $P$ \\
\hline Age, years & $70.40 \pm 13.46$ & $68.60 \pm 13.74$ & 0.128 & $70.26 \pm 14.19$ & $68.67 \pm 13.53$ & 0.189 & $68.23 \pm 13.50$ & $70.19 \pm 13.90$ & 0.055 \\
\hline Male, \% & 106 (60.92) & $356(62.68)$ & 0.676 & $100(60.98)$ & 362 (62.63) & 0.670 & $268(60.50)$ & 194 (64.88) & 0.227 \\
\hline COPD, \% & $56(32.18)$ & $121(21.30)$ & 0.003 & $46(28.05)$ & $131(22.66)$ & 0.153 & $90(20.32)$ & $87(29.10)$ & 0.006 \\
\hline CVD, \% & $39(22.41)$ & $91(16.02)$ & 0.052 & $34(20.73)$ & $96(16.61)$ & 0.220 & $78(17.61)$ & $52(17.39)$ & 0.940 \\
\hline Hypertension, \% & $89(51.15)$ & $254(44.72)$ & 0.137 & $79(48.17)$ & $264(45.67)$ & 0.572 & 205 (46.28) & $138(46.15)$ & 0.974 \\
\hline DM, \% & $68(39.08)$ & $190(33.45)$ & 0.173 & 65 (39.63) & 193 (33.39) & 0.138 & $136(30.70)$ & $122(40.80)$ & 0.005 \\
\hline CHF, \% & $86(49.43)$ & $236(41.55)$ & 0.067 & $72(43.90)$ & $250(43.25)$ & 0.882 & $180(40.63)$ & $142(47.49)$ & 0.064 \\
\hline CRD, \% & $27(15.52)$ & $57(10.04)$ & 0.046 & $20(12.20)$ & $64(11.07)$ & 0.689 & $46(10.38)$ & $38(12.71)$ & 0.327 \\
\hline Tumor, \% & $23(13.22)$ & $55(9.68)$ & 0.183 & $24(14.63)$ & $54(9.34)$ & 0.051 & $35(7.90)$ & $43(14.38)$ & 0.005 \\
\hline $\mathrm{MBP}, \mathrm{mmHg}$ & $81.91 \pm 24.19$ & $92.33 \pm 18.88$ & $\begin{array}{l}< \\
0.001\end{array}$ & $82.34 \pm 23.99$ & $92.02 \pm 19.16$ & $\begin{array}{l}< \\
0.001\end{array}$ & $92.15 \pm 19.83$ & $86.53 \pm 21.54$ & $\begin{array}{l}< \\
0.001\end{array}$ \\
\hline $\begin{array}{l}\text { Respiratory rate, } \\
\text { beats/min }\end{array}$ & $31.95 \pm 7.33$ & $29.72 \pm 6.46$ & $\begin{array}{l}< \\
0.001\end{array}$ & $32.15 \pm 8.30$ & $29.70 \pm 6.13$ & $\begin{array}{l}< \\
0.001\end{array}$ & $29.91 \pm 6.27$ & $30.74 \pm 7.37$ & 0.110 \\
\hline Temperature, ${ }^{\circ} \mathrm{C}$ & $37.48 \pm 1.30$ & $37.41 \pm 1.13$ & 0.535 & $37.69 \pm 1.36$ & $37.35 \pm 1.10$ & 0.004 & $37.46 \pm 1.14$ & $37.37 \pm 1.22$ & 0.305 \\
\hline Heart rate, beats/min & $78.11 \pm 21.31$ & $107.20 \pm 31.20$ & $\begin{array}{l}< \\
0.001\end{array}$ & $116.60 \pm 21.69$ & $111.70 \pm 29.41$ & 0.079 & $109.30 \pm 21.25$ & $115.00 \pm 29.64$ & 0.002 \\
\hline $\mathrm{PaO}_{2}, \mathrm{mmHg}$ & $73.54 \pm 34.78$ & $84.15 \pm 31.45$ & $\begin{array}{l}< \\
0.001\end{array}$ & $66.49 \pm 29.17$ & $85.97 \pm 32.19$ & $\begin{array}{l}< \\
0.001\end{array}$ & $81.92 \pm 28.89$ & $81.29 \pm 37.37$ & 0.804 \\
\hline Lac, mmol/L & $4.47 \pm 3.69$ & $2.07 \pm 2.05$ & $\begin{array}{l}< \\
0.001\end{array}$ & $\begin{array}{l}2.60(1.50 \\
5.05)\end{array}$ & $1.50(0.90,2.50)$ & $\begin{array}{l}< \\
0.001\end{array}$ & $\begin{array}{l}1.50(1.00 \\
2.40)\end{array}$ & $2.00(1.10,4.20)$ & $\begin{array}{l}< \\
0.001\end{array}$ \\
\hline$P C T, n g / m L$ & $\begin{array}{l}1.50(0.28 \\
8.50)\end{array}$ & $\begin{array}{l}0.28(0.06 \\
1.75)\end{array}$ & $\begin{array}{l}< \\
0.001\end{array}$ & $\begin{array}{l}1.62(0.35 \\
9.53)\end{array}$ & $0.27(0.06,1.68)$ & $\begin{array}{l}< \\
0.001\end{array}$ & $\begin{array}{l}0.24(0.06 \\
1.44)\end{array}$ & $1.06(0.16,6.16)$ & $\begin{array}{l}< \\
0.001\end{array}$ \\
\hline $\mathrm{WBC}, \times 10^{9} / \mathrm{L}$ & $\begin{array}{l}12.77(8.23 \\
18.97)\end{array}$ & $\begin{array}{l}11.22(7.99 \\
15.66)\end{array}$ & $\begin{array}{l}< \\
0.001\end{array}$ & $\begin{array}{l}12.70(7.73 \\
17.67)\end{array}$ & $\begin{array}{l}11.34(8.11 \\
15.88)\end{array}$ & 0.229 & $\begin{array}{l}12.30(8.38 \\
16.82)\end{array}$ & $12.30(7.80,15.88)$ & 0.111 \\
\hline $\mathrm{PaO}_{2} / \mathrm{FiO}_{2}$ & $\begin{array}{l}199.70 \pm \\
105.10\end{array}$ & $\begin{array}{l}246.20 \pm \\
104.50\end{array}$ & $\begin{array}{l}< \\
0.001\end{array}$ & $165.40 \pm 71.61$ & $255.20 \pm 4.42$ & $\begin{array}{l}< \\
0.001\end{array}$ & $239.08 \pm 96.05$ & $229.76 \pm 120.05$ & 0.262 \\
\hline CRP & $42.39 \pm 5.25$ & $41.59 \pm 5.06$ & 0.037 & $43.09 \pm 5.30$ & $41.58 \pm 5.06$ & $\begin{array}{l}< \\
0.001\end{array}$ & $41.59 \pm 5.06$ & $42.39 \pm 5.25$ & 0.037 \\
\hline qSOFA score & $1.96 \pm 0.76$ & $1.35 \pm 0.62$ & $\begin{array}{l}< \\
0.001\end{array}$ & $1.98 \pm 0.70$ & $1.36 \pm 0.64$ & $\begin{array}{l}< \\
0.001\end{array}$ & $1.38 \pm 0.63$ & $1.66 \pm 0.77$ & $\begin{array}{l}< \\
0.001\end{array}$ \\
\hline SOFA score & $9.58 \pm 5.11$ & $5.38 \pm 4.18$ & $\begin{array}{l}< \\
0.001\end{array}$ & $9.21 \pm 4.85$ & $5.56 \pm 4.41$ & $\begin{array}{l}< \\
0.001\end{array}$ & $5.66 \pm 4.08$ & $7.40 \pm 5.45$ & $\begin{array}{l}< \\
0.001\end{array}$ \\
\hline CURB-65 score & $3.16 \pm 1.23$ & $2.19 \pm 1.19$ & $\begin{array}{l}< \\
0.001\end{array}$ & $3.29 \pm 1.17$ & $2.17 \pm 1.18$ & $\begin{array}{l}< \\
0.001\end{array}$ & $2.22 \pm 1.20$ & $2.71 \pm 1.30$ & $\begin{array}{l}< \\
0.001\end{array}$ \\
\hline
\end{tabular}

COPD chronic obstructive pulmonary disease, $C V D$ Cerebrovascular disease, $D M$ Diabetes mellitus, $C H F$ chronic heart failure, $C R D$ chronic renal dysfunction, $M B P$ myelin basic protein, Lac lactate, PCT: p rocalcitonin, WBC white blood cell, CRP C-reactive protein, qSOFA quick sequential organ failure assessment, SOFA sequential organ failure assessment, CURB-65 confusion, urea, respiratory rate, blood pressure and age 
Table 2 Binary Logistic regression analysis of clinical outcomes for CAP patients

\begin{tabular}{|c|c|c|c|c|c|c|}
\hline & Variables & $\beta$ & S.E & Wald & $P$ & OR $(95 \% \mathrm{Cl})$ \\
\hline \multirow[t]{10}{*}{ ICU-admission } & WBC & 0.017 & 0.009 & 3.244 & 0.072 & $1.017(0.999-1.035)$ \\
\hline & $\mathrm{PCT}$ & -0.004 & 0.004 & 1.071 & 0.301 & $0.996(0.987-1.004)$ \\
\hline & CRP & 0.176 & 0.024 & 54.278 & $<0.001$ & $1.192(1.138-1.249)$ \\
\hline & Lac & 0.204 & 0.043 & 22.208 & $<0.001$ & $1.227(1.127-1.335)$ \\
\hline & $\mathrm{PaO}_{2}$ & -0.010 & 0.006 & 3.578 & 0.059 & $0.990(0.979-1.000)$ \\
\hline & $\mathrm{PaO}_{2} / \mathrm{FiO}_{2}$ & -0.001 & 0.002 & 0.476 & 0.490 & 0.999 (0.995-1.002) \\
\hline & qSOFA & 0.343 & 0.215 & 2.547 & 0.110 & $1.409(0.925-2.146)$ \\
\hline & SOFA & 0.115 & 0.027 & 17.518 & $<0.001$ & $1.122(1.063-1.184)$ \\
\hline & CURB-65 & 0.394 & 0.114 & 11.956 & $<0.001$ & $1.483(1.186-1.854)$ \\
\hline & Constant & -10.900 & 1.163 & 87.884 & $<0.001$ & \\
\hline \multirow[t]{10}{*}{ ARDS } & WBC & -0.010 & 0.012 & 0.699 & 0.403 & $0.990(0.967-1.014)$ \\
\hline & $\mathrm{PCT}$ & 0.002 & 0.004 & 0.169 & 0.681 & 1.002 (0.994-1.010) \\
\hline & CRP & 0.031 & 0.022 & 1.986 & 0.159 & $1.031(0.988-1.077)$ \\
\hline & Lac & 0.029 & 0.041 & 0.511 & 0.475 & $1.030(0.950-1.116)$ \\
\hline & $\mathrm{PaO}_{2}$ & -0.006 & 0.006 & 1.108 & 0.292 & $0.994(0.983-1.005)$ \\
\hline & $\mathrm{PaO}_{2} / \mathrm{FiO}_{2}$ & -0.010 & 0.002 & 26.917 & $<0.001$ & $0.990(0.987-0.994)$ \\
\hline & qSOFA & 0.473 & 0.223 & 4.519 & 0.034 & $1.605(1.038-2.484)$ \\
\hline & SOFA & 0.090 & 0.029 & 9.661 & 0.002 & $1.094(1.034-1.159)$ \\
\hline & CURB-65 & 0.483 & 0.118 & 16.712 & $<0.001$ & $1.621(1.286-2.043)$ \\
\hline & Constant & -2.787 & 1.012 & 7.591 & 0.006 & \\
\hline \multirow[t]{10}{*}{ 28-day mortality } & WBC & 0.005 & 0.008 & 0.487 & 0.485 & 1.005 (0.990-1.020) \\
\hline & $\mathrm{PCT}$ & 0.004 & 0.004 & 1.252 & 0.263 & $1.004(0.997-1.012)$ \\
\hline & CRP & 0.013 & 0.016 & 0.712 & 0.399 & $1.013(0.983-1.045)$ \\
\hline & Lac & 0.129 & 0.035 & 13.619 & $<0.001$ & $1.138(1.062-1.219)$ \\
\hline & $\mathrm{PaO}_{2}$ & -0.000 & 0.004 & 0.000 & 0.993 & $1.000(0.992-1.008)$ \\
\hline & $\mathrm{PaO}_{2} / \mathrm{FiO}_{2}$ & 0.000 & 0.001 & 0.001 & 0.969 & $1.000(0.998-1.003)$ \\
\hline & qSOFA & 0.096 & 0.158 & 0.367 & 0.544 & $1.100(0.808-1.499)$ \\
\hline & SOFA & 0.034 & 0.020 & 2.833 & 0.092 & $1.034(0.994-1.075)$ \\
\hline & CURB-65 & 0.196 & 0.081 & 5.901 & 0.015 & $1.216(1.039-1.424)$ \\
\hline & Constant & -2.251 & 0.706 & 10.171 & 0.001 & \\
\hline
\end{tabular}

WBC white blood cell, PCT procalcitonin, CRP C-reactive protein, Lac lactate, qSOFA quick sequential organ failure assessment, SOFA sequential organ failure assessment, CURB-65 confusion, urea, respiratory rate, blood pressure and age

Table 3 The characteristics for various predictors of ICU-admission in CAP patients

\begin{tabular}{|c|c|c|c|c|c|c|c|c|c|c|}
\hline Variables & AUC (95\% Cl) & S.E & $P$ & Cut off & Sensitivity & Specificity & PPV & NPV & LR+ & LR- \\
\hline Lac & $0.745(0.712-0.776)$ & 0.022 & $<0.001$ & 2.3 & 64.37 & 75.18 & 43.3 & 87.3 & 2.59 & 0.47 \\
\hline РСТ & $0.641(0.605-0.676)$ & 0.023 & $<0.001$ & 1.0 & 50.00 & 73.98 & 37.2 & 82.8 & 1.92 & 0.68 \\
\hline WBC & $0.563(0.527-0.599)$ & 0.027 & 0.019 & 18.48 & 28.16 & 85.21 & 36.8 & 79.5 & 1.90 & 0.84 \\
\hline CRP & $0.721(0.687-0.753)$ & 0.023 & $<0.001$ & 44.01 & 59.77 & 75.53 & 42.8 & 86.0 & 2.44 & 0.53 \\
\hline qSOFA & $0.712(0.678-0.745)$ & 0.021 & $<0.001$ & 1.0 & 70.11 & 65.32 & 38.2 & 87.7 & 2.02 & 0.46 \\
\hline SOFA & $0.744(0.711-0.775)$ & 0.021 & $<0.001$ & 6.0 & 67.24 & 68.84 & 39.8 & 87.3 & 2.16 & 0.48 \\
\hline CURB-65 & $0.705(0.671-0.738)$ & 0.022 & $<0.001$ & 3.0 & 44.25 & 85.74 & 48.7 & 83.4 & 3.10 & 0.65 \\
\hline
\end{tabular}



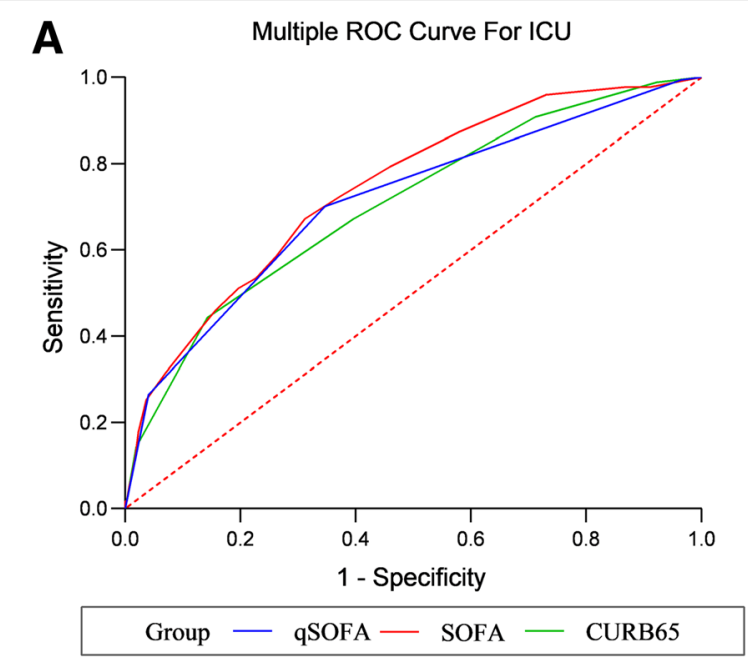

\section{B}

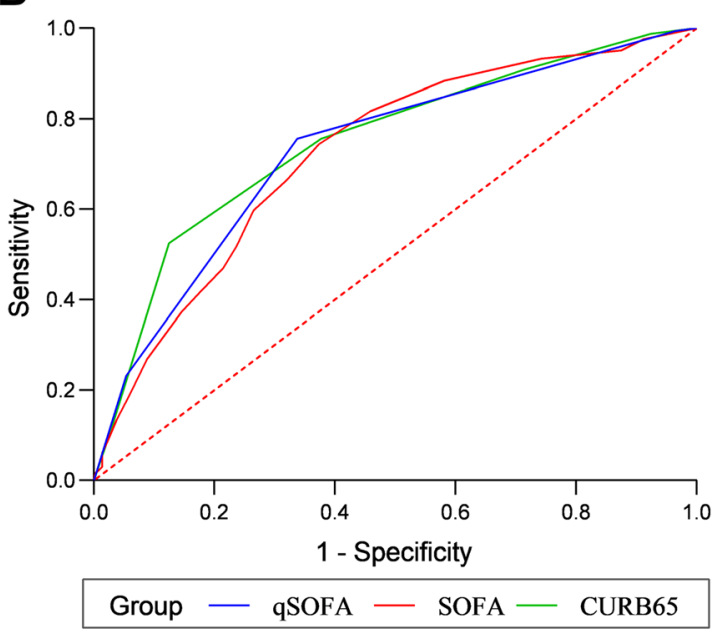

C

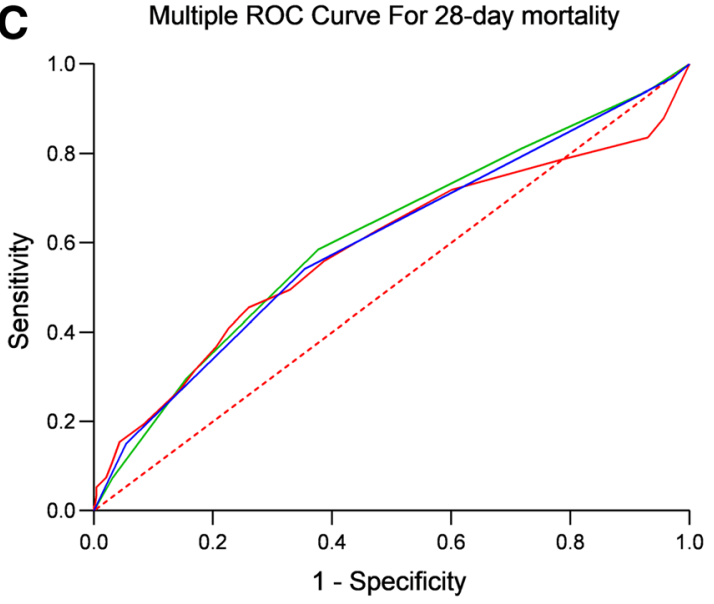

Group - qSOFA - SOFA - CURB65

Fig. 1 ROC curves of various predictors in prognostic outcomes in outcomes among CAP patients. a ICU-admission; b ARDS; c 28-day mortality incomplete clinical data had other diseases except CAP, 61 participants were lost to follow-up, and 73 patients or relatives did not agree to be enrolled. Finally, 742 patients completed 28 days of follow-up. The baseline data of the patients with CAP were shown in Table 1.

In the present study, 742 CAP patients were divided into ICU $(n=174)$ and non-ICU $(n=568)$ admission groups. There were significant differences in chronic obstructive pulmonary disease $(\mathrm{COPD})(P=0.003)$, chronic renal dysfunction $(\mathrm{CRD})(P=0.046)$, MBP $(P<0.001)$, respiratory rate $(P<0.001)$, heart rate $(P<0.001), \mathrm{PaO}_{2}$ $(P<0.001)$, Lac $(P<0.001)$, PCT $(P<0.001), \mathrm{WBC}(P<$ $0.001), \mathrm{PaO}_{2} / \mathrm{FiO}_{2}(P<0.001)$, CRP $(P=0.037)$, qSOFA score $(P<0.001)$, SOFA score $(P<0.001)$ and CURB-65 score $(P<0.001)$ between ICU and non-ICU admission groups (Table 1 ).

According to CAP patients with or without ARDS, 742 cases were classified as ARDS $(n=164)$ and non-ARDS $(n=578)$ groups. Obvious differences between ARDS and non-ARDS groups were discovered in MBP $(P<$ $0.001)$, respiratory rate $(P=0.002)$, temperature $(P=$ $0.004), \mathrm{PaO}_{2}(P<0.001)$, Lac $(P<0.001)$, PCT $(P<$ $0.001), \mathrm{PaO}_{2} / \mathrm{FiO}_{2}(P<0.001)$, CRP $(P<0.001)$, qSOFA score $(P<0.001)$, SOFA score $(P<0.001)$ and CURB-65 score $(P<0.001)$ (Table 1$)$.

After 28 days of follow-up, we also found that the statistical differences were distinct in COPD $(P=0.006)$, DM $(P=0.005)$ tumor $(P=0.005)$, MBP $(P<0.001)$, heart rate $(P=0.013)$, Lac $(P<0.001)$, PCT $(P<0.001), \mathrm{PaO}_{2} / \mathrm{FiO}_{2}$ $(P<0.001)$, CRP $(P<0.001)$, qSOFA score $(P<0.001)$, SOFA score $(P<0.001)$ and CURB-65 score $(P<0.001)$ between survivor $(n=443)$ and non-survivor $(n=299)$ groups (Table 1).

\section{Binary logistic regression analysis of the prognostic outcomes for CAP patients}

As displayed in Table 2, the results showed that the differences were significant in the CRP level $(P<0.001, \mathrm{OR}=$ 1.192, 95\%CI: $1.138-1.249)$, Lac level $(P<0.001$, OR $=1.227$, 95\%CI: $1.127-1.335)$, SOFA $(P<0.001, \mathrm{OR}=1.122,95 \% \mathrm{CI}$ : 1.063-1.184) and CURB-65 scores $(P<0.005, \mathrm{OR}=1.483$, $95 \%$ CI: $1.186-1.854)$ on ICU-admission. It was indicated that the CRP level, Lac level, SOFA and CURB-65 scores was the risk factors of ICU-admission among CAP patients. For the occurrences of ARDS, the qSOFA $(P=0.034$, OR $=1.605$, 95\%CI: $1.038-2.484)$, SOFA $(P=0.002, \mathrm{OR}=1.094,95 \% \mathrm{CI}$ : $1.034-1.159)$ and CURB-65 scores $(P<0.001, \mathrm{OR}=1.621$, 95\%CI: 1.286-2.043) were the risk factors, while the $\mathrm{PaO}_{2} /$ $\mathrm{FiO}_{2}$ ratio $(P<0.001, \mathrm{OR}=0.990,95 \% \mathrm{CI}$ : $0.987-0.994)$ was as a protective factor among the patients with CAP. The Lac level $(P<0.001, \quad \mathrm{OR}=1.138,95 \% \mathrm{CI}: 1.062-1.219)$ and CURB-65 scores $(P=0.015$, OR $=1.216,95 \% \mathrm{CI}$ : 1.039 1.424) were the risk factors of the 28-day mortality in CAP patients. 
Table 4 The characteristics for various predictors of ARDS in CAP patients

\begin{tabular}{|c|c|c|c|c|c|c|c|c|c|c|}
\hline Variables & AUC $(95 \% \mathrm{Cl})$ & S.E & $P$ & Cut off & Sensitivity & Specificity & PPV & NPV & LR+ & LR- \\
\hline Lac & $0.690(0.655-0.723)$ & 0.023 & $<0.001$ & 2.1 & 61.59 & 69.20 & 36.2 & 86.4 & 2.00 & 0.56 \\
\hline PCT & $0.662(0.627-0.696)$ & 0.023 & $<0.001$ & 0 & 68.29 & 59.48 & 32.5 & 86.8 & 1.69 & 0 \\
\hline WBC & $0.531(0.494-0.567)$ & 0.027 & 0.260 & 12.6 & 51.83 & 58.48 & 26.2 & 81.1 & 1.25 & 0.82 \\
\hline CRP & $0.587(0.550-0.622)$ & 0.025 & 0.001 & 40.8 & 71.34 & 42.91 & 26.2 & 84.1 & 1.25 & 0.67 \\
\hline qSOFA & $0.730(0.697-0.762)$ & 0.021 & $<0.001$ & 1.0 & 75.61 & 66.26 & 38.9 & 90.5 & 2.24 & 0. \\
\hline SOFA & $0.724(0.690-0.756)$ & 0.022 & $<0.001$ & 5.0 & 74.39 & 62.63 & 36.1 & 89.6 & 1.99 & 0.4 \\
\hline CURB-65 & $0.749(0.716-0.780)$ & 0.022 & $<0.001$ & 3.0 & 52.44 & 87.54 & 54.4 & 86.6 & 4.21 & \\
\hline
\end{tabular}

Lac lactate, $P C T$ procalcitonin, WBC white blood cell, CRP C-reactive protein, qSOFA quick sequential organ failure assessment, SOFA sequential organ failure assessment, CURB-65 confusion, urea, respiratory rate, blood pressure and age

\section{Prediction of the prognostic outcomes in CAP patients}

The predictive analysis of the relevant parameters for CAP patients in various outcomes were depicted in Table 34 and 5, and the ROC curves of predictive effects of the scoring systems for CAP patients were shown in Fig. 1. The AUC values of the qSOFA, SOFA and CURB-65 scores for ICU-admission among CAP patients were 0.712 (95\%CI: $0.678-0.745, P<0.001), 0.744$ (95\%CI: $0.711-0.775, \quad P<0.001)$ and 0.705 (95\%CI: $0.671-0.738, P<0.001)$, respectively. The cut-off values for the qSOFA, SOFA and CURB-65 scores maximizing the composite of specificity and sensitivity in the prediction of CAP patients in ICU-admission were 1.0, 6.0 and 3.0 (Table 3 and Fig. 1a). For ARDS, the AUC values of the qSOFA, SOFA and CURB-65 scores were 0.730 (95\%CI: $0.697-0.762, P<0.001), 0.724$ (95\%CI: $0.690-$ $0.756, P<0.001)$ and 0.749 (95\%CI: 0.716-0.780, $P<$ 0.001 ), respectively (Table 4 and Fig. 1b). After 28 days of follow-up, the AUC values of the qSOFA, SOFA and CURB-65 scores for 28-day mortality were 0.602 (95\%CI: $0.566-0.638, P<0.001$ ), 0.587 (95\%CI: $0.551-$ 0.623, $P<0.001)$ and 0.614 (95\%CI: 0.577-0.649, $P<$ 0.001 ) in turn (Table 5 and Fig. 1c).

Comparison of AUCs for predicting the prognostic outcomes among CAP patients were analyzed in the study. The results revealed that there were no statistical differences between qSOFA and SOFA scores for predicting ICU-admission $(\mathrm{Z}=1.482, P=0.138)$, ARDS
$(\mathrm{Z}=0.321, P=0.748)$ and 28 -day mortality $(\mathrm{Z}=0.573$, $P=0.567)$. Moreover, we found no differences to predict the ICU-admission $(Z=0.370, P=0.712)$, ARDS $(\mathrm{Z}=0.900, P=0.368)$ and 28 -day mortality $(\mathrm{Z}=0.768$, $P=0.442)$ using qSOFA or CURB-65 scores.

\section{Discussion}

CAP is one of serious diseases that causes death and threatens human life. Establishment of safe and effective prognostic assessment systems of CAP is important for clinicians. In the present study, we investigated the predictive value of qSOFA for the clinical outcomes including ICU-admission, ARDS and 28-day mortality in emergency patients with $\mathrm{CAP}$, and the efficacy of the qSOFA score was assessed in comparison with CURB-65 and SOFA scores. Our results revealed that qSOFA was not inferior to SOFA or CURB-65 scores in predicting the ICU-admission, ARDS and 28-day mortality of patients presenting in the ED with CAP.

Pneumonia is a common reason for hospitalization [18], and CAP is associated with the high risk of respiratory failure or septic organ dysfunction. The early managements of CAP are also based on severity assessment tools since 2000, including CURB-65 [19-21], pneumonia severity index (PSI) [21-23] and so on. In 2007, the Infectious Diseases Society of America/American Thoracic Society consensus guidelines suggested PSI and CURB-65 scoring systems be used together [24]. Subsequently, newly published guidelines suggested that the

Table 5 The characteristics for various predictors of 28-day mortality in CAP patients

\begin{tabular}{|c|c|c|c|c|c|c|c|c|c|c|}
\hline Variables & AUC (95\% Cl) & S.E & $P$ & Cut off & Sensitivity & Specificity & PPV & NPV & $\mathrm{LR}+$ & LR- \\
\hline Lac & $0.611(0.575-0.646)$ & 0.022 & $<0.001$ & 2.3 & 45.48 & 73.59 & 53.8 & 66.7 & 1.72 & $\overline{0.74}$ \\
\hline PCT & $0.624(0.588-0.659)$ & 0.020 & $<0.001$ & 0 & 59.80 & 62.08 & 51.3 & 69.8 & 1.58 & 0.65 \\
\hline WBC & $0.534(0.498-0.571)$ & 0.022 & 0.115 & 11.68 & 54.85 & 54.63 & 44.9 & 64.2 & 1.21 & 0.83 \\
\hline CRP & $0.537(0.501-0.574)$ & 0.022 & 0.083 & 45.3 & 28.09 & 78.56 & 46.9 & 61.8 & 1.31 & 0.92 \\
\hline qSOFA & $0.602(0.566-0.638)$ & 0.019 & $<0.001$ & 1.0 & 54.18 & 64.56 & 50.8 & 67.6 & 1.53 & 0.71 \\
\hline SOFA & $0.587(0.551-0.623)$ & 0.022 & $<0.001$ & 7.0 & 45.48 & 74.04 & 54.2 & 66.8 & 1.75 & 0.74 \\
\hline CURB-65 & $0.614(0.577-0.649)$ & 0.021 & $<0.001$ & 2.0 & 58.53 & 62.30 & 51.2 & 69.0 & 1.55 & 0.67 \\
\hline
\end{tabular}

Lac lactate, $P C T$ procalcitonin, WBC white blood cell, CRP C-reactive protein, qSOFA quick sequential organ failure assessment, SOFA sequential organ failure assessment, CURB-65 confusion, urea, respiratory rate, blood pressure and age 
pneumonia severity can be assessed utilizing the SOFA and qSOFA scores. Nevertheless, the efficacies of these scoring systems for predicting the prognostic outcomes are still matters of controversy in emergency patients with CAP. As we know, the calculation of PSI is really complex that involving 20 parameters [22], which is not suitable for newly admitted patients in ED. The CURB65 score consists of confusion, urea, respiratory rate, blood pressure and age that is similar with the qSOFA score in components. The SOFA score was proposed by European Society of Intensive Care Medicine (ESICM) in 1994 [25], and was applied for prognostic assessments in sepsis and multiple organ dysfunction, which was associated with the mortality. The qSOFA, incorporating hypotension, altered mental status and tachypnea, was high prediction of mortality in non-ICU settings [26]. In our study, the qSOFA, SOFA and CURB-65 scoring systems were applied for mortality prediction in patients with CAP.

Our findings found that the predictive performances of the qSOFA and CURB-65 scores in ICU-admission, ARDS and 28-day mortality were similar $(P>0.05)$. The qSOFA score is a quick and simple scoring system which is to identify the elevated risks in clinical deterioration, which was associated with ICU-admission in adult ED patients [27]. Goulden et al [28] reported that the efficacy of the qSOFA was as similar as Systemic Inflammatory Response Syndrome (SIRS) and National Early Warning Score (NEWS) for predicting ICU-admission. Early researches mentioned that a positive qSOFA score had high specificity outside the ICU in early detection of ICU admission [14]. Previous studies reported that the CURB-65 score was related to the risk of ARDS in CAP patients, and the development of ARDS risk was prominent when the CURB-65 score was $\geq 2$ [29]. The CURB65 score contains respiratory rate $\geq 30$ beats $/ \mathrm{min}$ and systolic blood pressure $<90 \mathrm{mmHg}$ or diastolic blood pressure $\leq 60 \mathrm{mmHg}$, which the thresholds of these indicators were higher than that in qSOFA (respiratory rate $\geq 22$ beats $/ \mathrm{min}$ and systolic blood pressure $\leq 100$ $\mathrm{mmHg}$ [13]). Compared with the qSOFA score, CURB65 may miss some potentially dangerous patients in the risk prediction. A recent systematic review suggested that the positive qSOFA score had high specificity in early detection of in-hospital mortality [14]. A multiplecenter research discovered that the CURB-65 score had a predictive value of mortality in CAP patients [30]. In the presented study, the predictive values of the qSOFA and CURB-65 scores were similar regarding to the ICUadmission, ARDS and 28-day mortality. The discrepancy may be due to differences in the variables assessed, the patient group and the study design. In consideration of needing quick and effective diagnose in the ED, therefore the qSOFA score may be a useful and practical tool for the early prediction of ARDS and 28-day morality among patients with CAP, and may serve as an early warning signal that CAP is about to worsen in emergency patients.

The superiority of this study was that few previous researches had investigated the predictive value of qSOFA score in comparison with other pneumonia severity scoring systems (SOFA and CURB-65 scores) in the prognostic outcomes containing ICU-admission, ARDS and 28-day mortality for CAP patients, especially in Chinese population. However, there were some limitations that should be warranted caution for interpreting the data. Our investigation was a retrospective study based on a single center. Microbiology, time to initiation of antibiotics and antibiotic choice may be potential confounding variables. The 28 -day mortality as a prognostic outcome was assessed, but long-term outcomes were not identified. Thus, prospective multicenter studies with larger samples should be needed for further verification in clinic.

\section{Conclusion}

In this study, we found that the predictive effects of qSOFA score were similar with CURB-65 and SOFA scores in ICU-admission, ARDS and 28-day mortality. According to the actual situation of emergency patients, qSOFA score may be an effective and practical tool for the early prediction of ICU-admission, ARDS and 28day morality among CAP patients in the ED.

\section{Abbreviations \\ qSOFA: Quick sequential organ failure assessment; CAP: Community-acquired pneumonia; ED: Emergency department; ARDS: Acute respiratory distress syndrome; AUC: Area under the curve; ICU: Intensive care unit; IMV: Invasive mechanical ventilation; EDTA: Ethylenediaminetetraacetate; WBC: White blood cell; PCT: Procalcitonin; LOD limit of detection; CRP: C-reactive protein; SD: Standard deviation; AUC: Area under curves; PPV: Positive predictive value; NPV: Negative predictive value; COPD: Chronic obstructive pulmonary disease; CFD: Chronic renal dysfunction; PSI: Pneumonia severity index; ESICM: European Society of Intensive Care Medicine; SIRS: Systemic Inflammatory Response Syndrome; NEWS: National Early Warning Score}

\section{Acknowledgements \\ The authors are thankful to all the subjects for their participation in the study.}

\section{Authors' contributions}

$\mathrm{HZ}, \mathrm{XQZ}$ and $\mathrm{BL}$ designed the study. XQZ drafted and wrote the manuscript. YGL and LJM contributed to collected, analyzed and interpreted the data. $\mathrm{HZ}$ and BL critically reviewed, edited and approved the manuscript. All authors read and approved the final manuscript.

\section{Funding}

The design of the study, the collection, analysis and interpretation of data and in writing the manuscript were supported by Beijing Chao-Yang Hospital middle-aged and young cultivation Funds (No. YQ2014-30).

\section{Availability of data and materials}

The data used and/or analyzed during the current study are available from the corresponding author on reasonable request. 


\section{Ethics approval and consent to participate}

This study was approved by the Institutional Review Board of Beijing ChaoYang Hospital (No.2014-KE-124). All written informed consents were obtained from all participants and/or their legal guardians. Firstly, patients who conformed to the inclusion and exclusion criteria were screened in this study. Secondly, we notified patients and/or their legal guardians by telephone and asked for consent, and for those who did not, we waived the use of their data. Thirdly, we sent written informed consents to patients and/or their legal guardians who agreed to participate in the study for signature. Finally, they returned the signed informed consents to us.

\section{Consent for publication}

Not applicable.

\section{Competing interests}

The author reports no conflicts of interest in this work.

Received: 18 October 2019 Accepted: 19 April 2020

Published online: 29 April 2020

\section{References}

1. Musher DM, Thorner AR. Community-acquired pneumonia. N Engl J Med. 2014;371(17):1619-28.

2. Welte T, Torres A, Nathwani D. Clinical and economic burden of community-acquired pneumonia among adults in Europe. Thorax. 2012; 67(1):71-9.

3. Leoni D, Rello J. Severe community-acquired pneumonia: optimal management. Curr Opin Infect Dis. 2017;30(2):240-7.

4. Fan E, Brodie D, Slutsky AS. Acute respiratory distress syndrome advances in diagnosis and treatment. JAMA. 2018;319(7):698-710.

5. Song H, Moon HG, Kim SH. Efficacy of quick sequential organ failure assessment with lactate concentration for predicting mortality in patients with community-acquired pneumonia in the emergency department. Clin Exp Emerg Med. 2019:6(1):1-8.

6. Ranzani OT, Prina E, Menendez R, Ceccato A, Cilloniz C, Mendez R, et al. New sepsis definition (Sepsis-3) and community-acquired pneumonia mortality a validation and clinical decision-making study. Am J Respir Crit Care Med. 2017;196(10):1287-97.

7. Kim MW, Lim JY, Oh SH. Mortality prediction using serum biomarkers and various clinical risk scales in community-acquired pneumonia. Scand J Clin Lab Investig. 2017;77(7):486-92.

8. Kofoed K, Eugen-Olsen J, Petersen J, Larsen K, Andersen O. Predicting mortality in patients with systemic inflammatory response syndrome: an evaluation of two prognostic models, two soluble receptors, and a macrophage migration inhibitory factor. Eur J Clin Microbiol Infect Dis. 2008; 27(5):375-83.

9. Ilg A, Moskowitz A, Konanki V, Patel PV, Chase M, Grossestreuer AV, et al. Performance of the CURB-65 score in predicting critical care interventions in patients admitted with community-acquired pneumonia. Ann Emerg Med. 2019;74(1):60-8.

10. Espana PP, Capelastegui A, Mar C, Bilbao A, Quintana JM, Diez R, et al. Performance of pro-adrenomedullin for identifying adverse outcomes in community-acquired pneumonia. J Infect. 2015;70(5):457-66.

11. Lim WS, van der Eerden MM, Laing R, Boersma WG, Karalus N, Town Gl, et al. Defining community acquired pneumonia severity on presentation to hospital: an international derivation and validation study. Thorax. 2003;58(5): 377-82.

12. Espana PP, Capelastegui A, Gorordo I, Esteban C, Oribe M, Ortega M, et al. Development and validation of a clinical prediction rule for severe community-acquired pneumonia. Am J Respir Crit Care Med. 2006;174(11): 1249-56.

13. Singer M, Deutschman CS, Seymour CW, Shankar-Hari M, Annane D, Bauer $M$, et al. The third international consensus definitions for sepsis and septic shock (Sepsis-3). JAMA. 2016;315(8):801-10.

14. Song JU, Sin CK, Park HK, Shim SR, Lee J. Performance of the quick sequential (sepsis-related) organ failure assessment score as a prognostic tool in infected patients outside the intensive care unit: a systematic review and meta-analysis. Crit Care. 2018;22:28-40.

15. Asai N, Watanabe H, Shiota A, Kato H, Sakanashi D, Hagihara M, et al. Efficacy and accuracy of qSOFA and SOFA scores as prognostic tools for community-acquired and healthcare-associated pneumonia. Int J Infect Dis. 2019;84:89-96.

16. Niederman MS, Mandell LA, Anzueto A, Bass JB, Broughton WA, Campbell GD, et al. Guidelines for the management of adults with communityacquired pneumonia - diagnosis, assessment of severity, antimicrobial therapy, and prevention. Am J Respir Crit Care Med. 2001;163(7):1730-54.

17. Ranieri VM, Rubenfeld GD, Thompson BT, Ferguson ND, Caldwell E, Fan E, et al. Acute respiratory distress syndrome the Berlin definition. JAMA. 2012; 307(23):2526-33.

18. WHO Global Health Observatory (GHO). http://www.who.int/gho/mortality burden_disease/causes_death_2008/en/index.html; Accessed 2018.

19. British Thoracic Society Standards of Care Committee. BTS guidelines for the management of community acquired pneumonia in adults-synopsis. Thorax. 2001;56:1-64.

20. Capelastegul A, Espana PP, Quintana JM, Areltio I, Gorordo I, Egurrola M, et al. Validation of a predictive rule for the management of communityacquired pneumonia. Eur Respir J. 2006;27(1):151-7.

21. Chen JH, Chang SS, Liu JJ, Chan RC, Wu JY, Wang WC, et al. Comparison of clinical characteristics and performance of pneumonia severity score and CURB-65 among younger adults, elderly and very old subjects. Thorax. 2010; 65(11):971-7.

22. Fine MJ, Auble TE, Yealy DM, Hanusa BH, Weissfeld LA, Singer DE, et al. A prediction rule to identify low-risk patients with community-acquired pneumonia. N Engl J Med. 1997;336(4):243-50.

23. Buising KL, Thursky KA, Black JF, MacGregor L, Street AC, Kennedy MP, et al. A prospective comparison of severity scores for identifying patients with severe community acquired pneumonia: reconsidering what is meant by severe pneumonia. Thorax. 2006;61(5):419-24.

24. Mandell LA, Wunderink RG, Anzueto A, Bartlett JG, Campbell GD, Dean NC, et al. Infectious Diseases Society of America/American Thoracic Society consensus guidelines on the management of community-acquired pneumonia in adults. Clin Infect Dis. 2007;44:S27-72.

25. Vincent JL, Moreno R, Takala J, Willatts S, DeMendonca A, Bruining H, et al. The SOFA (sepsis-related organ failure assessment) score to describe organ dysfunction/failure. Intensive Care Med. 1996;22(7):707-10.

26. Seymour CW, Liu VX, Iwashyna TJ, Brunkhorst FM, Rea TD, Scherag A, et al. Assessment of clinical criteria for sepsis for the third international consensus definitions for sepsis and septic shock (Sepsis-3). JAMA. 2016;315(8):762-74.

27. Singer AJ, Ng J, Thode HC, Spiegel R, Weingart S. Quick SOFA scores predict mortality in adult emergency department patients with and without suspected infection. Ann Emerg Med. 2017;69(4):475-9.

28. Goulden R, Hoyle MC, Monis J, Railton D, Riley V, Martin P, et al. qSOFA, SIRS and NEWS for predicting inhospital mortality and ICU admission in emergency admissions treated as sepsis. Emerg Med J. 2018;35(6):345-9.

29. Liu KT, Yang KY, Lee YC, Perng RP. Risk factor analysis of acute respiratory distress syndrome among hospitalized patients with chlamydophila pneumoniae pneumonia. J Chin Med Assoc. 2007;70(8):318-23.

30. Ewig S, Birkner N, Strauss R, Schaefer E, Pauletzki J, Bischoff H, et al. New perspectives on community-acquired pneumonia in 388406 patients. Results from a nationwide mandatory performance measurement programme in healthcare quality. Thorax. 2009;64(12):1062-9.

\section{Publisher's Note}

Springer Nature remains neutral with regard to jurisdictional claims in published maps and institutional affiliations.

Ready to submit your research? Choose BMC and benefit from:

- fast, convenient online submission

- thorough peer review by experienced researchers in your field

- rapid publication on acceptance

- support for research data, including large and complex data types

- gold Open Access which fosters wider collaboration and increased citations

- maximum visibility for your research: over $100 \mathrm{M}$ website views per year

At $\mathrm{BMC}$, research is always in progress.

Learn more biomedcentral.com/submissions 